\title{
普通地水田に於ける硫酸還元菌による 水稻苗の被害に就て
}

野瀨久義

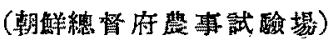

(昭和 15 年 5 月 30 日受領)

Hisayosi NOSE: On the injury of rice-seedlings caused by sulfate-reducing bacteria in common paddy-field.

\section{I 緒吉}

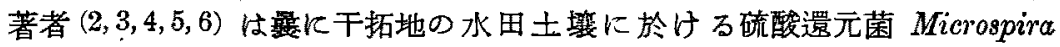
desulfuricans (BEIJERINCK) von DELDEN K關する研究を行ひ，本細菌は干拓 地の水田土壤に於て繁殖極めて旺盛にして，水槄はこれがために幼苗に笍敗を 生じ，又指积後に於ても生育に障害を受くることを報告せり。其の後著者は普 通地水田土壤に稓ける本障害に關して研究を行ひたり。從來普通地水田土壤に 於け五本障害の發生阔しては，昭和 13 年及び 14 年に大杉及び川口氏 $(7,8$,

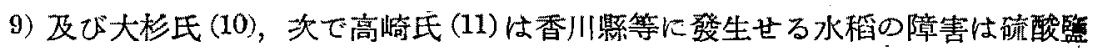
類の還元作用と密接なる關係を有することを報じ，又最近户荷氏 (12) 仕埼玉縣 鴻巣に發生せる水稻の障害は、硫酸還元菌の存在及び硫酸監の施用によることを

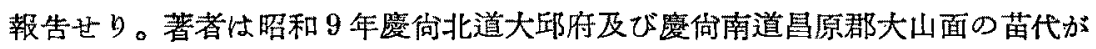
管敗し，又插秋後の水田に\&著しく被害の發生せるを調查したる外，其の他の 各地よりる屡々斯加る障害に關する報告を受けたるにより，これ等障害の原因 が干拓地に於けるものと同一交りやに關し研究を行ひたり。本報告虫其の得た る結果の大要を錄せるものとす。

\section{II 被害地並に被害の狀況}

著者の觀察したる被害水田は慶向北道大邱府及び慶晌南道昌原郡大山面にあ クたるものにして，次に其の狀沉を述ぶべし。

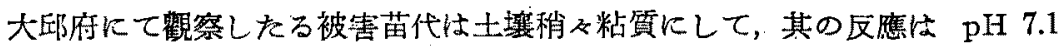


〜7.2を呈し，市街地よりは䋓えず下水の流入により有機質に富めり。次に被 害の狀態を检するに被害籹の接觸せる部分の土壤面及び其の內部には硫化鐵の 黑色沈凯を集積し, 、又土壤中に殘存せる草木片等は何れ8黑色を呈せり。被害 は幼芽の 1 3 cm に伸長せるものに顯著にして, 被害苗の幼芽は本葉を抽出 せず，鞘葉は瀻弱にして殆んど葉綠を成生せずして色を呈し，多くは其の基 部又は先端部が蘶曲し，軟化，枯死せり。又其の根ば生育を抑制せられ枯死し， 黑色を呈せり。

次に慶少南道昌原郡大山面の被害土壤は稍々粘質にして有機質に富み，且つ 排水不良なるがため下水の如惡息を有し，其の反應は $\mathrm{pH} 7.3$ な。幼苗の 被害狀態は大邱府に發生せるする同樣にして其の程度は 32〜50\%に達せり。 佾同年 8 月上旬同地方に搟秧せる水稻の生育狀況を調査したるに，水稻は分藮 數少く，草長は低くして且つ不揃ひと应り，其の葉は淡色を呈して外葉より枯 死に頻せる8のありたるも, 其の大部分は葉色却つて濃く所及に稻熱病の發生

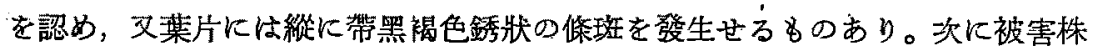
の根張りは極めて不良にして容易に拢取り得られ，其の根部は附近の土壤々 共に全く黑色を呈せり。斯かる根は著しく生氣を失ひ其の大部分は队部組織が 褐變して軟化，枯死し，別に地際部附近より新根の發生せるものありたり。

\section{III 被害毕より病原菌の分離及び接種試驗}

著者は前迅の被害苗に病原菌の存するや否やを確めんとし，細菌分離の目的 そてブイヨン寒天を，又絲枵菌分離のためには乾杏斯汁寒天及び稻葉前汁寒天 を用ひて分離を行ひ， $20^{\circ} \mathrm{C}$ の定溫器に收めたり。然る時哬れの場合に於て 子新鮮疗る材料上りは何者をも分離し得ず、又軟化, 腐敗せる古き材料上りは, 灰白色，黃色及び稀に淡赤色の聚落を作れる細菌を得たるも，其の出現は不定 にして，且つ水稻幼苗及び附稘粐の登芽に對して寄生性を示ささりき。故にこ れ等の細菌は本障害の病原菌に㤹あらさるもの之認めらる。

\section{IV，被害苗代土壤の硫酸還元作用}

著者は被害苗代土壤に於ける硫酸還元作用を驗知せんとし，前記の慶佾北道 大邱府及び夢何南道昌原郡大山面より採集せる土壤を供試し試驗を行ひたり。 其の方法は $100 \mathrm{cc}$ エルンンマイヤーフラスコに van DELDEN 氏培盖液 $50 \mathrm{cc}$ を注入して殺菌を行ひ（反應は $\mathrm{pH} 6.9$ )，これに供試土壤䄪 $5.0 \mathrm{~g}$ を接種して， 
其の液面に流勤パラフィンを重學したる後 $30^{\circ} \mathrm{C}$ の定溫器に收めたり。然る時 は培養 1 日後には培盖液が污白色に混溷し，2〜3 日にして黑色の沈澱を生じて

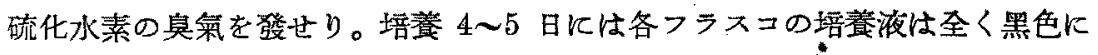

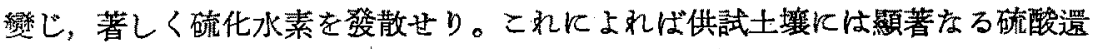
元作用の存在せるを知る。

\section{$\mathrm{V}$ 被害苗代土壤より硫酸還元菌及び其の隨件菌の分離}

本貫驗には大邱府及び大山面の被害苗代土培を使用せり。其の方法は前記の 被害苗代土壤を接種せる培養液を探りて BURRI 氏法(1)により分離を行ひた り。然る時は必亦硫酸還元菌を分離し得たるのみならず，常に特殊の隨件菌を も分離せり。而して隨伴菌は純粹に培養し得たるも硫酸還元菌はこれを純粹に 培榐し得ざりしを以つて，其の培養は隨件菌との共生のま〉行ひたり。

\section{VI 硫 酸 還 元 菌}

\section{1 形 態}

（1）形狀 弧狀に彎曲せる螺损狀菌にして兩端は鈍に，孤立するか2 万至數 㑑體，或は多數連結す。大さはブイョン寒天に 24 時間培養せるもの石炭酸

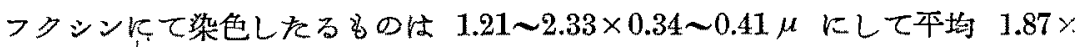
$0.35 \mu$ 疗り。

(2) 鞭毛 ブイヨン寒天 15 時間培養のものにつき PLIMMER 及び PAINE 氏法により鞭毛染色を行ひたるに，本細菌は體の一極江 1 本の鞭毛を有す。

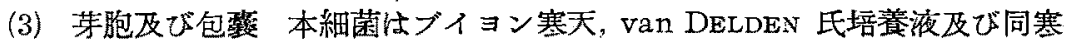

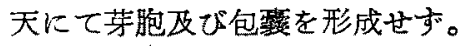

（4）染色性 本細菌はアンリン性色美を以つてよく染色せらる。Z Z1EHL及び NEELSEN 氏法による抗酸性染色法を以つて染色せられず。文 ATKINS 氏法に よる GRAM 氏染色の結果は陰性索り。

\section{2 唔羡基上に於ける性孟}

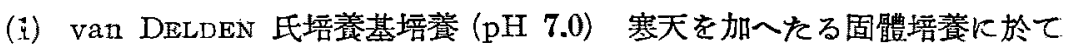
は黑色の聚落を生じ，基中に硫化鐵を成生す。又液體唔養にては硫化鐵の黑色 沈搌を生じ, 何れ子硫化水素を成生す。

(2) ブイョン閦質穿刺培養 $18^{\circ} \mathrm{C}$ にては 48 時間にして穿刺線に沿ひて帶 蕫狀 (Napiform) 次で蹗狀 (Saccate) に溶解し, 通常 1 週間を經過すれば培養 
基の太部分を液化し惡具を放つ。

（3）牛乳培養 48 時間にしてカゼインの凝固を始め管底に沈降し，上澄液は 透明晾り。

（4）リトマス牛乳培養 24 時間にしてリトマスを脫色し，次で管の上㞗部に 橙赤色の着色を生ず。

(5) CoHN 氏液咥養 發育せす”。

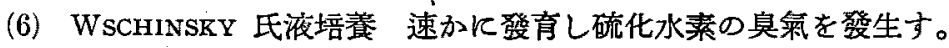

\section{3 生理 的性 椞}

（1）酸素の要否 純様氣性細菌にして嫌氣的培養により或は隨件菌との共生 によりてのみ發育す。

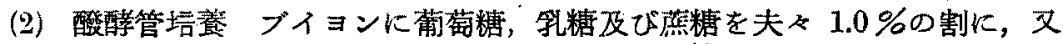
グリセリンを $4.0 \%$ 割に加へて培㐿するに，本細菌は其の何れにも發育し， 且つ瓦斯老生文。

（3）硫化水素の成生 本細菌は各㮔の培養基にて硫化水素の成生䫛著なり。 殊に van DELDEN 氏培養液にては硫酸監を還元して硫化水素を發散し液中に 硫化鐵の黑色沈澱を多量に成生せり。

(4) インドールの成生 ブイヨン培目に於てインドールの成生顯著なり。

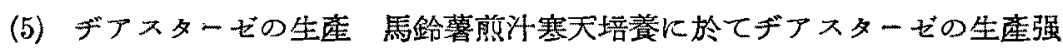
きを認めたり。

(6)，会糖培養基に於ける酸の成生 本細菌はリトマス牛乳を橙赤色に着色す るは前迅せる如くをり。及ズイヨンに葡萄糖，乳糖及び菣糖を $1.0 \%$ 割に, グ リセリンを $4.0 \%$ 割に加人て培盖したるに何れも酸を成生せり。

（7）溫度と還元作用 van DELDEN 氏培養缏に於ける本細菌の硫酸鹽還元の 適溫仕 $30^{\circ} \sim 31^{\circ} \mathrm{C}$ 附近にして，最高溫度及び最低溫度は夫ね $40^{\circ} \mathrm{C}$ 及び $7^{\circ} \mathrm{C}$ 附近なり。又死隇溫度は $55^{\circ} \mathrm{C}$ なり

（8）含監量と還元作用 van DELDEN 氏培養液に於て硫酸監の還元に好適 せる食監の含量は $0 \sim 0.8 \%$ とて其の最適含量は $0 \sim 0.5 \%$ ○。其の最高 限度は $7.0 \%$ 疗り。

（9）墡善基の反應と還元作用 van DELDEN 氏培養液を用ひて檢したる所に よれば本細菌の硫酸監還元作用は $\mathrm{pH} 5.9 \sim 9.3$ の範圍に於て行はれ其の最適 は $\mathrm{pH} 7.3 \sim 7.5$ なり。 
著者 (2)）が鼠に記迅したる如く從來硫酸息元菌として報告せられたる細菌は Microspira desulfuricans (BEIJERINCK) van DELDEN, Microspira Aestuarii van DELDEN 及び Vibrio thermodesulfuricans ELION の3種にして，これ等 は何れる大さは $4.0 \times 1.0 \mu$ にして體の一極に 1 本の鞭毛を有し, 形態的には差 異を認めざるも，生理的性質，就中含盬量と發育との關係及び發育要溫の兩性 質の相違によりて區別せらる。郎ち Microspira Aestuarii van DELDEN は van DELDEN 氏培養液にて純好監性にして且つ著しく含監量の高き培養基を好 みて䇣殖し，又 Vibrio thermodesulfuricans ELION は發育要溫極めて高く其の 最滴溫度は $55^{\circ} \mathrm{C}$, 最高溫度及び最低溫度は夫ょ $65^{\circ} \mathrm{C}$ 及び $30^{\circ} \mathrm{C}$ の附近にあり。 又 Microspira desulfuricans (BEIJERINCR) van DELDEN は繁殖に好適する培䍱 基の含監量は菌株によりて多少の差翼あるが如しと雖も，何れの菌株子無監の

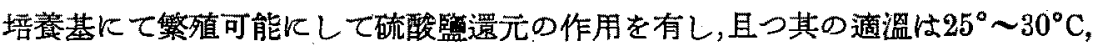
就中 $28^{\circ} \mathrm{C}$ にして $37^{\circ} \mathrm{C}$ に於ても佾よく其の力を有す。今これを著者の硫酸還 元菌に見るに大さは多少小なるも稍ぬ一致し，無監の van DELDEN 氏培養液 にて繁殖良好にして，硫酸監の還元作用旺盛なるのみならす，其の還元作用の 適溫士 $30^{\circ} \sim 31^{\circ} \mathrm{C}$ 附近, 最高溫度及び最低溫度は夫ょ $40^{\circ} \mathrm{C}$ 及び $7^{\circ} \mathrm{C}$ 附近 反存す。斯加る性質は Microspira desulfuricans (BEIJERINCK) van DELDEN

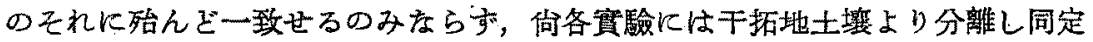
したる Microspira desulfuricans (BEIJERINCK) van DELDEN を比較として使 用したるによく一政せる結果を得たるを以つて本細菌は干拓地土褧の硫酸還元 菌とは同一種に屬するものと認むへくく，從つてこれを Microspira desulfuricans (BEIJERINCK) van DELDEN に同定せんとす。

\section{VII 隨 伴 菌}

\section{1 形 態}

（1）形狀 兩端鈍圆なる短程狀菌にして，通常坬生するも時に 2 万系多數個 體連結し絲狀をなすことあり。大さはブイョン寒天に 24 時間培養せるものを 石炭酸フクシンにて染色し檢鏡するに 1.30〜1.95×0.72〜1.14 $\mu$ にして平㚬 $1.48 \times 0.97 \mu$ あり。

(2) 鞭毛 プイヨン寒天に 15 時間培養のものにつを PLIMMEN 及び PAINE 氏法により鞭毛染色を行ひたるに，本細菌は體の一極上り 1〜3本，多くの個 體は 3 本の鞭毛を有す。 
（3）芽胞及び包豪 本細菌はブイヨン寒天，van DELDEN 氏培養液及び同寒 天にて芽胞及び包变を形成せず。

（4）染色性 本細菌は各種のアニリン性色素を以つてよく染色せらる。ZIEHL 及び NEELSEN 氏法による抗酸性染色法にて染色せられず。丈ATKINS 氏法 ・による GRAM 氏染色の結果は陰性なり。

\section{2 培養基上に於ける性算}

（1）Van DELDEN 氏培養基培養 寒天を加へたる扇平培養にありては，24時 間にして淡乳灰色の脆弱なる聚落を生し，これは中高(Convex), 全圆 (Circular), 平滑 (Smooth)にして澋光を有す。斜面培養にては劃線に湝して繁殖し淡乳灰 色を是す。又其表面は平滑にして濕光を有し，凝水は淡乳灰色となりて混溷 す。穿刺培養にては穿刺溝內の發育は絲狀（Filiform）にして上部の菌厤は周 緣針鋸蓞狀を呈す。又寒天を加へたる液體培養にては 24 時間にして混溷を生 す。倘固體培養にありては菌層の附近より文液體培養にては液の上層より鮮明 なる淡黃綠色乃至黃綠色 (Light Viridine Green 乃至 Viridine Green) の着 色を生ず。

（2）ブイョン普盖 寒天を加へたる屚本培養にありては，24時間にして淡黃 乳灰色にして濕光を有する脆弱なる祭落を生じ, これ初め中高(Convex), 全 圆 (Circular), 平滑 (Smọoth) なるも後周緣稍不覞則となりて中央部稍隆起す。 父液體培養にては速かに混溷を生じて液面に被膜を作る。命培養液は上層より 淡綠色を帶ぶ。

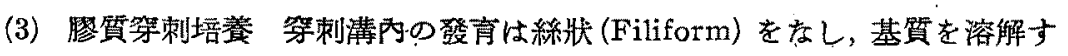
ることなし。

（4）牛乳培養 カゼインを凝固することなく, 液は上層より漸次淡黃綠色 (Pale Lumiere Green) К着色す。

(5)リト、ース牛乳培養 培養液は上層より青變す。

(6) COHN 氏液培養 發育せす。

（7）WschInsky 氏液培養 上層より混溷を始め, 鱼綠色 (Viridine Green) 着色す。又其の液面には脆弱なる白色の被膜を生す。

3 生理 的性質

(1) 酸素の要否 本細菌は通性好氣性菌に屬す̣。

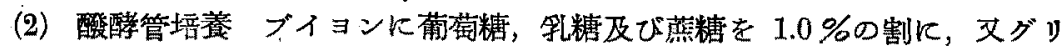
セリンを $4.0 \%$ 割に加へて培養を行ふに何れる開管部側に混溷を生し，瓦斯 
の發生を認めす。

（3）硫化水素の成生 Van DELDEN 氏培養液及びブイョン培養に於て何れ 硫化水素の發生を證せず。

（4）インドールの成生 本細菌はブイヨン培養に於てインドールを成生せす。

(5) デアスターゼの生產 本細菌は馬鈴暮煎汁寒天唔養に於てヂテスターゼ の生制は殆んど認められざか或付微弱なり。

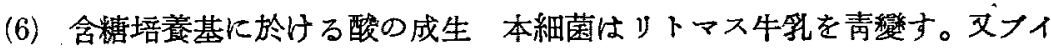
ヨンに葡萄糖，乳糖及び苲糖を夫ょ $1.0 \%$ 割に，グリセリンを $4.0 \%$ 割に 加へて培養を行ひたるに葡仵糖を加へたる培養液のみ僅かに酸性を是せるる其 の他の培養液にては却つて僅汃に監基性を堌加せり。

（7）溫度と發育 van DELDEN 氏普養基を以つて检するに，本細菌の發育 の適溫は $30^{\circ} \sim 33^{\circ} \mathrm{C}$ にして最高溫度は $40^{\circ} \mathrm{C}$, 最低沮度は $3^{\circ} \mathrm{C}$ 附近なり。又 死減溫度は $55^{\circ} \mathrm{C}$ 度り。

（8）反磪と發育 van DELDEN 氏培飬液を用して檢したるに本細菌の發育 に最適する培液の反應は $\mathrm{pH} 7.1 \sim 7.3$ Kして, 其の限界は $\mathrm{pH} 5.0$ 及び $\mathrm{pH}$ 9.3 附近店り。

（9）含監量と發育 van DELDEN 氏培養液を用ひて檢したるに本細菌の繁 殖に最適せる培養液の含監量は $0.5 \%$ 附近にして, 亞で無盬の場合に於て發育 良好なり。又其の最高限度は 11.0 ～ $13.0 \%$ 附近に存す。

\section{4 分類學的考察}

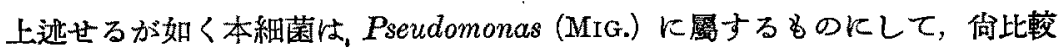
として使用せる干拓地土壤の隨伴菌とは其の性狀殆んど相一致せしが故に，こ

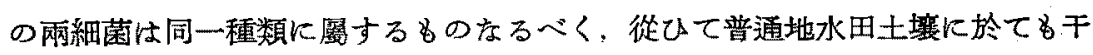
拓地土壤に於けると同一種類に屬する隨伴菌が存在せるを知れり。

\section{IX 被害の發生と硫酸還元菌と.關係。}

次に著者は被害苗代の土壤と被害の發生との關係を明加にし，又これと同時 に被害苗代土壤より分離せる硫酸還元菌の水稻苗に及伍す作用を知らんとし試 驗を行ひたり。省本實驗には比較のため干沰地の被害苗代土壤より分離せる硫 酸還元菌及び其の隨伴菌の混合培養を供試せり。實驗の方法は縱，橫及び㳭 さ夫々 $90 \mathrm{~cm}, 90 \mathrm{~cm}$ 及び $21 \mathrm{~cm}$ を有する木製框 14 個を用意し，當場の試 驗水田土壤を細粉となして高厴にて充分殺菌したる後，これに分ち入れ，更に 
殺菌井水を注入して水田狀態となし，これを次の如を試驗區に分ちたり。但し 各試驗區は何れる 1 區に木製框 2 個を供用せり。其の試驗區は矢の如し。

第 1 區 土壤の表層に大邱府より探取せる被害苗代土壤を多量に加一僅かに 㩭找す。

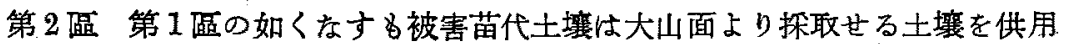
す。

第 3 區 高壓にて充分殺菌したる大邱府の被害苗代土壤を多量に加へ，これ に同土壤より分離せる硫酸還元菌及び其の隨伴菌を混舍接種す。

第4區第3 區の如くなする充分殺菌したる大山面の被害苗代土壤を加八， これに同土锖より分離せる硫酸還元菌及び其の隨件菌を混合接種す。

第5區嵪塺にて充分殺菌したる大山面の被害苗代土壤を多量に加人，これ に干拓地の被害苗代土壤より分離せる硫酸還元菌及び其の隨件菌を 泥合接種す。

第 6 剾高壓にて充分殺菌したる大山面の被害苗代土壤を多量に加へ僅かに 㩭拌す。

第7區 對照として其の睢供用す。

各區の框は周圍の空を開放せる室內に置を，1 日間を經過したる後，選種を 行ひ $80 \%$ \%ルコール次で 1000 倍の晨永液にて消毒をなし殺菌井水にて立 分洗橴したる無せ愛國種を播蓮せり。但し粐の播種は 5 月 24 日に行ひたり。 其の結果は次の如し。

\begin{tabular}{|c|c|c|c|c|c|c|c|c|}
\hline & & & & 腐 & 苗 & 生 & 育苗 & \\
\hline 試駸的 & & & 繁 & $\begin{array}{l}\text { 應敢 } \\
\text { 苗数 }\end{array}$ & 鷹敗苗 & 生竟 & |生有苗 & 備 \\
\hline 第 & 1 & 睼 & 1000 & 204 & $20.4^{\%}$ & 796 & $79.6^{3 \%}$ & 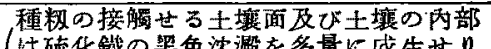 \\
\hline & 2 & & 1000 & 267 & 26.7 & 733 & 73.3 & 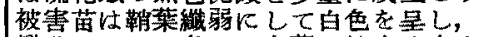 \\
\hline & 3 & & 1000 & 214 & 21.4 & 786 & 78.6 & 棃曲せるるの多し。本集の抽出は完全 \\
\hline & 4 & & 1000 & 252 & 25.2 & 748 & 74.8 & 稂は著しく抑制せられ僅汃に伸長せる \\
\hline & 5 & & 1000 & 246 & 24.6 & 754 & 75.4 & 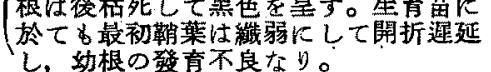 \\
\hline & 6 & & 1000 & 0 & 0 & 1000 & 100.0 & 土腋は黑色を是することなく種极の發 \\
\hline . & 7 & & 1000 & 0 & 0 & 1000 & 100.0 & 芽及び幼苗の生育には䣏常を認めず。 \\
\hline
\end{tabular}

上表は各區共何れ－定の個所に於て10000粒に就さて調査したる 2 框の本均 なり。これによれば被害苗代土壤を加八，或はそれより分離せる硫酸還元菌及 び其の隨体菌を殺菌せる被害苗代土埣に接種して種粐を播種すれば幼苗に腐敗 
を生じ，土壀には硫化鐵の黑色沈激を集積す。又殺菌せる被害苗代土壤に被害， 干拓地苗代土壤上り分離せる硫酸摆元菌及び其の隨件菌を接種せる場合に於て る同㥞にして, 其の被害の狀熊に柱全く差異を認めさりき。然る江殺菌せる被害 苗代土壤及び虽場の水田土壤に播㮔せる場合には何れる支障なく生育をなせり。 これによりて見れ被害苗代土壤に於ける幼苗腐敗は土壤に原因を有し，而加 もそれは千拓地に於けると同樣にして硫酸還元菌の繁殖によるるのと認めらる。

$$
\mathrm{X} \text { 摘 要 }
$$

1. 著者は器に干拓地の水田土壤に於て硫酸還元菌 Microspira desulfuricuns (BEIJERINCK) van DELDEN の旺盛度る繁殖に上り惹起さるる水稻氻苗の 被害に關して報告したるが，本報告にはこれと同樣なる被害現像が普通地水田 土㖶に於ても存在せる事實を迅べたるるのなり。

2. 被害發生の土壤は稍々粘質にして，疆篮基性を呈し，有機質に富める排

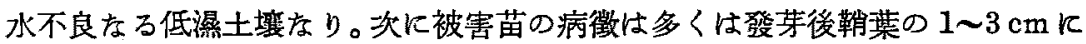

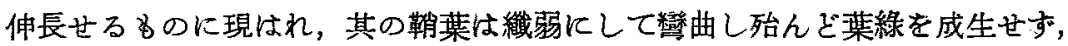
本葉の發達は極めて微弱にして開析することなく枯死，腐敗す。及其の根は生

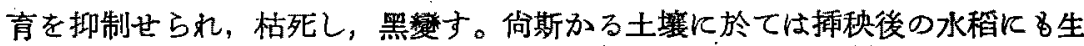
育障害を發生せり。

3. 被害幼苗より绀如何存る病原菌をも分離し得ざりき。

4. 被害苗代土壤に法硫酸還元作用極的て旺盛にして，これより細菌の分離 を行ふ時柱常に硫酸還元菌及び其の隨件菌を分離し得られる。而しててれ等の 細菌は, Microspira desulfuricans (BEIJERINCK) van DELDEN 及び Pseudomonas sp. に圂し，干拓地の被害苗代土蛮に於ける細菌と全く同一種に屬せるを認め たり。

5. 當場の詿驗圈場より探取せる水田土壤を殺菌し，これに被害苗代土㙲を 加へて種柽を摇種すれば，自然狀態にて發生せる病徵と酷似せる被害苗を生じ， 其の土壤恃黑化して, 被害苗代土壤と同样度る狀態を呈せり。而して斯加る被 害の狀態は被害苗代土壤及び暴に著者の報告したる千拓地の被害苗代土壤より 分離せる硫酸還元菌及び其の隨伴菌を混合接種したる場合に現はる〉被害の狀 熊子異劣る所なし。

6. これを要するに本被害は硫酸還元菌, Mierospira desulfuricans (BEIJERINCK） van DELDEN の繁殖によるものにして，干拓地苗代に於ける被害現象 
と同樣なる原因によるものと認的るる。

\section{引用 交 跃}

1. BURRI R.: $Z$ ur Isolierung der Anäeroben. Centrbl. Bakt., Abt. II, Bd. 8, S. $533,1902$.

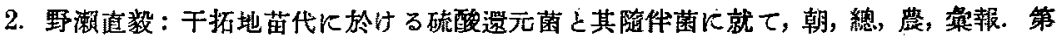
7 甞, 219 頁, 昭和 9 年 (1934).

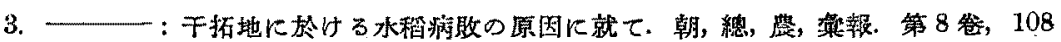
頁, 昭和 11 年 (1935).

4. 一一：干拓地火於け，る水简苗の腐敗に就て，日本植，病，會報. 第 6 兊，172 貣, 昭和 11 年 (1936).

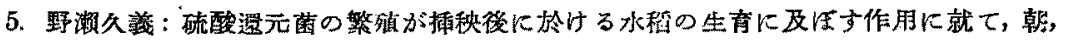

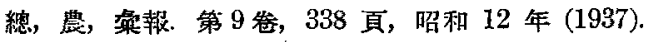

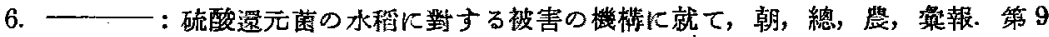
得, 351 頁, 昭和 12 年 (1937).

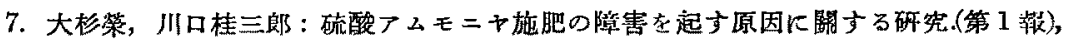
土, 盵, 雜誌, 第 12 忩, 298 頁, 昭和 13 年 (1938).

8: 一一，一：水田に於ける研酸丁ムモニヤ施肥による障害に就て(第 1 報)， 土, 肥, 䧴誌, 第 12 檍, 453 頁, 昭和 13 年 (1938).

9. 一，一：水田に於ける硫酸アンモニア施肥に上る障害に就て(第2 赤)， 土. 盵, 雜誌, 第 13 怣, 1 頁, 昭和 14 年 (1939).

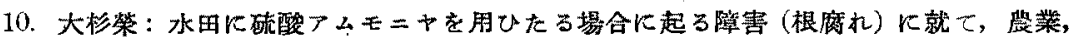
第 706 號，1 頁, 昭和 14 年 (1939).

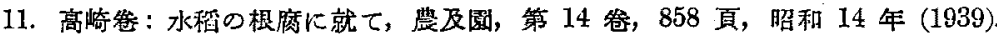

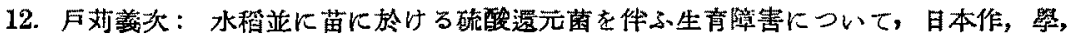
紀事，第 11 淁，353 頁，昭和 14 年 (1939)。

\section{Summary.}

The writer has already reported that, in the seed-bed of rice in tidal paddy-field of Tyosen where sulphate-reducing bacteria, Microspira desulfuricans (BEIJERINCK) van DELDEN, took an active and vigorous part, and that the rotting of rice-seeds and seedlings prevailed as the consequence of a great lack of oxygen.

This paper reports that injury in the same manner occurs also in common paddy-fields.

The injured soils investigated by the writer contain much of organic matters in addition to stagnation of water, and the reaction 
of soil is weak alkaline $(\mathrm{pH} \quad 7.1 \sim 7.3)$. The symptom appears on germ elongated to $1 \sim 3 \mathrm{~cm}$ of cotyledon as a germ with curvature and check of the elongation of the first leaf, which becomes dead and rots with age, and the growth of its root is checked, and then withers with a black colouration of the precipitation of iron sulphite.

In the injured soils, sulfate-reduction is very visible, and sulfate-reducing bacteria and the specially associated organisms have been isolated. Those bacteria are found to be identical with Microspira desulfuricans (BEIJERINCK) van DELDEN, and Pseudomonas sp. respectively which had been isolated by the writer from tidal paddy-fields, after comparing their morphological, cultuarl, and physiological characters.

From the results of experiments, these injurious soil conditions are not only closely resembles to those of tidal paddy-fields, but they are also similar to the conditions produced by the inoculation of sulfate-reducing bacteria, Microspira desulfuricans (BEIJERINCK) van DELDEN, in sterilized soil. 